\title{
Urban greening: a review of some Indian studies
}

\section{Pradeep Chaudhry}

Indian Institute of Forest Management, P. B. No. 357, Nehru Nagar, Bhopal-462003. India. Email: pradeepifs@yahoo.com

\begin{abstract}
Urban greenery generates many tangible and intangible benefits and contributes to improving environmental quality, quality of life and sustainable urban development. Research on various aspects of urban vegetation such as carbon sequestration, removing air pollutants, reducing noise, providing recreational amenity benefits is in infancy stage in India. This paper reviews few significant studies in different spheres of urban greenery from Indian cities. Some issues related to development and research in this direction and future management strategies to be adopted have been discussed.
\end{abstract}

Keywords: Urban vegetation; Air quality improvement; Recreation and amenity value; Ecosystem services; India.

\section{Introduction}

Urbanization is a phenomenon occurring in cities of India at a fast pace and putting pressure on the urban environment. This process is being fueled by population explosion throughout world particularly in developing countries (Leindfield and Steinberg, 2012). During last 50 years the population of India has grown two and half times but the urban population has grown nearly five times (Taubenböck, 2009). Urban green spaces play an important role in improving the quality of life in an urban ecosystem, particularly in a highly dense populated country like India. A well maintained and
Received

September 20, 2016

Accepted

December 22, 2016

Released

December 31, 2016

Open Acess

Full Text Article

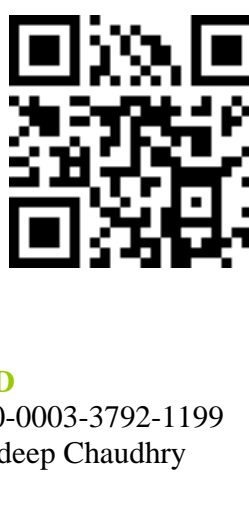

ORCIID

() 0000-0003-3792-1199

Pradeep Chaudhry healthy green space network in urban settings can provide many ecological benefits. For example in maintaining water quality, reducing storm water runoff (Sanders, 1986; Xiao et al., 1998; Xiao and McPherson, 2002); reducing heat island effect (Akbari and Konopacki, 2004; Gill et al., 2007); sequestering carbon dioxide (McPherson, 1998; Jo, 2002); reducing air pollution (Nowak et al., 2006; Yang et al., 2008); enriching aesthetic and recreational avenues for urban communities (Attwell, 2000; Chaudhry 2006; Jim and Chen, 2006) and enhancing property value (Morales 1980, Anderson and Cordell 1988, Tyrvainen 1997, 2001; Tyrvainen and Miettinen 2000; Chaudhry et al., 2013). 


\section{Some significant studies from India}

World Health Organization (WHO) and United Nations Food and Agricultural Organization (FAO) have advocated for $9 \mathrm{~m}^{2}$ green open space per person in urban areas (Kuchelmeister, 2000), whereas developed countries (mostly European and
USA) have adopted a general standard of green space of $20 \mathrm{~m}^{2}$ per person (Wang et al., 2007; Singh et al., 2010). Situation in most of the Indian cities, except Gandhinagar and Chandigarh, needs considerable improvement on this front (Table 1).

Table 1. Per capita green space of some Indian cities.

\begin{tabular}{lcccc}
\hline City & $\begin{array}{c}\text { Geographical } \\
\left.\text { area } \mathbf{( k m}^{2}\right)\end{array}$ & $\begin{array}{c}\text { Population in million } \\
\text { (census 2011) }\end{array}$ & $\begin{array}{c}\text { Forest and tree } \\
\left.\text { cover } \mathbf{( k m}^{\mathbf{}}\right)\end{array}$ & $\begin{array}{c}\text { Per capita green } \\
\text { space } \mathbf{( m}^{2} / \mathbf{i n h a b i t a n t )}\end{array}$ \\
\hline Bangalore & 226.00 & 8.43 & 150.00 & 17.80 \\
Chennai & 174.00 & 8.69 & 9.00 & 1.03 \\
Delhi & 435.00 & 16.31 & 297.81 & 18.27 \\
Mumbai & 735.00 & 18.48 & 122.00 & 6.60 \\
Hyderabad & 172.00 & 7.74 & 3.87 & 0.50 \\
Kolkata & 186.23 & 14.11 & 0.00 & 0.00 \\
Gandhinagar & 75.00 & 0.20 & 30.75 & 148.00 \\
Chandigarh & 114.00 & 1.05 & 49.00 & 46.67 \\
\hline
\end{tabular}

Source: Modified from Govindarajulu (2014).

Nagpur City of India with per capita green space of $31 \mathrm{~m}^{2}$ has much lesser concentrations of $\mathrm{SO}_{2}, \mathrm{NO}_{2}$ and RSPM well within permissible limits. A study was conducted in five zones of the city where three zones having better tree cover were found to have lesser $\mathrm{SO}_{2}, \mathrm{NO}_{2}$ and RSPM concentrations in comparison to other two zones having poor tree cover (Chaturvedi et al., 2013). In another study, biochemical responses to the impact of air pollution were studied in respect of four plant species namely Bougainvellia spectabilis, Azadirachta indica, Pongamia pinnata and Polyalthia longifolia in Nagpur City. Air Pollution Tolerance Index (APTI) was found highest for Azadirachta indica, making this species most suitable as sink for air pollution in polluted cities. The level of pollutants namely suspended particulate matter (SPM), $\mathrm{NO}_{2}$ and $\mathrm{SO}_{2}$ was found highest at commercial site followed by industrial and then residential site. Vegetation cover was found good at residential site, thereby giving enough indication about air pollutant absorption capacity of vegetation (Dhadse et al., 2011).
Bangalore is one of the fastest growing cities in India and facing increasing level of air pollution. Once known as ‘Garden City' of India, Bangalore is rapidly losing tree cover in public spaces including roads (Issar, 1994; Nair, 2005; Nagendra and Gopal, 2010). Still the city vegetation is playing a significant role in improving air quality. A study was conducted at 20 locations of the city and it was found that $\mathrm{SO}_{2}$ levels were reduced by $65 \%$ and afternoon ambient air temperature was found lower by $5.6^{\circ} \mathrm{C}$ in street segments with trees. Similarly, SPM levels were very high on exposed roads (without trees) with $50 \%$ of the roads showing levels approaching twice the permissible limits while $80 \%$ of the street segments with trees had SPM levels within prescribed limits (Vailshery et al., 2013). In a study conducted by Nagendra and Gopal (2010), Bangalore streets were found relatively low in density but high in species diversity when compared to other cities of Asia. Authors have concluded that large sized trees (having larger canopies) not being planted, leading to a greater predominance 
of young trees belonging to small sized species, which have lower capacity to absorb atmospheric pollutants, mitigate urban heat island effects and prevent ground water runoff. Nagendra et al. (2012) conducted a study focusing on changing patterns of vegetation cover in Bangalore City between 2000 and 2007. The authors found the core of the city well protected due to high land prices and other historical factors but vegetation clearing and fragmentation was more predominant in peripheral areas of the city. The tree species being planted were generally exotic demanding more water. This is likely to exacerbate the already significant challenges of water scarcity in the city.

Amongst all major cities of India, tree density (152 trees/ha) and tree cover (53.9\% of city area) are highest in Gandhinagar, the Capital of Gujarat (Singh, 2013; Chaudhry et al. 2011). Major tree species of the city include Peltroforum ferrruginieum, Azadirachta indica, Cassia fistula, Polyalthia longifolia, Cassia siamea, Delonix regia, Acacia nilotica, Albizia lebbeck, Alatonia scholaris, Ailanthus excelsa and Mangifera indica. RSPM concentration is found well within permissible limits at sector 8 and 23 monitoring station locations of Gandhinagar City, whereas this is not the case in industrial area of the city. The obvious reason is good tree density in residential areas of the capital city of Gujarat State of India (GPCB, 2015). In a study undertaken in 2011, total tree enumeration was done in all urban cities of Gujarat state. This was a first kind of such studies in the country. Thirty four cities and towns of the state were found to have adequate tree cover with tree density $>30$ trees/ha and rest 133 cities and towns of the state had low tree cover (Singh, 2013). A total of $1,060,281 \mathrm{t}$ of carbon $\left(3,900,051 \mathrm{t}\right.$ of $\mathrm{CO}_{2}$ equivalent) was removed annually in 2011 by about 6,413,000 (64.13 lakh) trees within a study area comprising Gandhinagar, Ahemedabad, Rajkot, Surat, Vadodara, Bhavnagar, Junagarh and Jamnagar. The researchers concluded that an average of $950 \mathrm{~kg}$ of carbon is sequestered and stored in the living biomass of trees at or above $350 \mathrm{~cm}$ girth breast height (GBH) during its entire lifespan. Contrary to it, average carbon sequestration potential of 10-60 cm GBH trees is only $29.6 \mathrm{~kg} /$ tree in its entire lifespan. Hence, it is necessary to conserve old and heritage trees (Parmar et al., 2015).

Khera et al. (2009) found a negative relationship between the density of exotic woody species especially Prosopis juliflora, the most abundant woody species in Delhi and bird species diversity. The authors recorded 56 bird species in 19 sampled green spaces of Delhi and recommended giving preferences to native species in the management plan of the urban green spaces in place of the exotics.

Dwivedi et al. (2009) quantified ecosystem services like biodiversity conservation and carbon sequestration in Kerwa Forest Area (KFA) of Bhopal City of Madhya Pradesh. Authors have pleaded for designating KFA as forest area/land from its present status of revenue land so as to provide adequate protection and providing essential forestry expertise for its sustainable management.

Chandigarh, a Union Territory itself and the Capital of Punjab and Haryana States, was established after India got independence in 1947. Urban greenery is integral part of city's landscaping and the Edict of city sets out the following underlying ideas in respect of landscaping: "The landscaping of this city is based on careful observation of the vegetation of India. Selected ornamental trees, shrubs and climbers have been planted according to colour scheme to beautify it. In future planting and replacements, these principles must be kept in view. There should be no haphazard replacements, so that the avenues retain their harmony and beauty. The Leisure Valley, the Rajendra Park and other parks shall be developed as parks only and no buildings other than already planned shall be permitted". In order to realize the objectives, a landscape advisory committee was constituted in 1953 under the chairmanship of Dr. M. S. Randhawa, then Development Commissioner Punjab, which meticulously guided the initial tree plantation of the city. It is still in existence, 
although under different chairpersons, as maintained by the Chandigarh administration from time to time (Singh et al., 1998). Some important tree avenues of the city include species like Ficus infectoria (Pilkhan), Alstonia scholaris (Devil's tree), Schleichera rijuga (Kusum), Terminalia arjuna (Arjun), Terminalia bellirica (Bahera), Swietenia mahagoni (Mahagony), Cassia fistula (Amaltas) Chukrasia tabularis (Chukrasia). In addition to above, tree species with attractive flowers in different seasons of the year and planted in various parks/gardens/roadsides include: Bauhinia purpurea, Bombax ceiba, Cassia javanica, Cassia nodosa, Cassia renigera, Cassia siamea, Delonix regia, Jacaranda mimosifolia, Koelreuteria apiculata, Lagerstroemia thorelli, Lagerstroemia rosea, Lagerstroemia speciossa, Lagerstroemia parviflora, Milletia ovalifolia, Parkinsonia aculeota, and Tecoma argentia.

Chandigarh City is among top Indian cities having forest and tree cover of more than $35 \%$ of its area and per capita green space availability around $55 \mathrm{~m}^{2}$ (Chaudhry and Tewari, 2011; Chaudhry et al., 2011; Chaturvedi et al., 2013). Maximum of the green space of the city is located in Northeast region (covering sectors 1 to 12) in comparison to Southwest region of the city (near Mohali. City of Punjab). Due to this fact, average concentration of Respirable Suspended Particulate Matter at PEC, sector 12 monitoring station has been found low (83 $\mu \mathrm{g} / \mathrm{m}^{3}$ ) in comparison to IMTECH, sector 39 monitoring station $\left(108.50 \mu \mathrm{g} / \mathrm{m}^{3}\right)$ between 2005-2011, though $\mathrm{SO}_{2}$ and $\mathrm{NO}_{\mathrm{x}}$ levels were found in limits throughout the city (Chaudhry et al., 2013). A study was conducted during 2002-2003 to estimate recreational benefits or use value of the Chandigarh City's urban greenery from the point of view of residents and domestic tourists using 'contingent valuation method' and 'travel cost method'. The annual recreational use value of the city's parks/gardens, boulevards, green avenues, reserved forests and wildlife sanctuary was estimated around Rs 120 million on the 2002-2003 price level (Chaudhry, 2006).
Reasons for careful selection of economic valuation methods like 'contingent valuation method', 'travel cost method' and 'hedonic pricing method'have also been highlighted by the authors (Chaudhry and Tewari, 2006; Chaudhry et al., 2007).

\section{Future management strategies}

Urban green spaces always remain in the public and media eye. These have to be managed on scientifically sound principles, which are transparent to public. These objectives can be met if options are compared and evaluated and management activities are continuously monitored on a short and long term basis (Gadow, 2002). There is lack of a comprehensive research database on urban greenery in the country. There is insufficient financial allocation for urban forestry development and research. To compete with other kind of municipal budgets, it is essential for urban forestry to raise its public profile and publicize its multiple contributions to the society (Chaudhry and Tewari, 2011).

Tree species emit Biogenic Volatile Organic Compounds (BVOCs) which lead to formation of ozone and carbon monoxide. BVOCs emission rates vary from species to species. In high traffic areas, tree species emitting BVOCs should be avoided (Curtis et al., 2014). There are few research studies/results available from India in this field, though much more needs to be done with respect to ornamental tree species planted in cities as avenue trees and in parks/gardens. Singh et al. (2008) evaluated 80 common Indian plant species for isoprene (a common VOC) used for planting programme. Out of these, 29 species were found moderate to high emitters, 12 species were low emitters and remaining 39 species were found to be negligible or non-emitters. The authors have mentioned that $50 \%$ plant species selected for planting programme in India were moderate to high emitters of isoprene. This trend needs to be changed and urban tree plantation agencies like forest department, horticulture department, municipal authorities in states and cities 
must take note of research findings for future plantation programmes.

Few studies related to estimating Air Pollution Tolerance Index (APTI) of tree species in urban environment are also available and practitioners in this field must take advantage of the findings. Air pollution tolerance index (APTI) of seven plant species growing in urban-industrial region of Allahabad City of Uttar Pradesh State was estimated by Kuddus et al. (2011). Out of seven tree species, Mangifera indica (with highest APTI) was found best as relatively tolerant species and Artocarpus species (with lowest APTI) as most sensitive to air pollutants. The sensitive (Artocarpus species) and tolerant species (Mangifera indica) can be used as bio-indicators to and as a sink for air pollutants, respectively. Rai and Panda (2014) used APTI and Anticipated Performance Index (API) values for assessing suitability of certain tree species for plantation in polluted roads of Mizoram State of India. Accordingly, Ficus bengalensis, Mangifera indica, Psidium guajava, Ficus religiosa, Artocarpus heterophyllus and Lagerstroemia speciosa were found suitable in given order for roadside plantation in polluted areas of North East Region of India. Particulate Abatement Capacity (PAC) of three commonly grown hedge species namely Bougainvillea spectabilis, Duranta plumeri and Nerium indicum was estimated in a study. The PAC of the hedge species was found in the order Duranta plumeri > Bougainvillea spectabilis > Nerium indicum. The authors also derived a formula for evaluation of the PAC of the hedge species (Varshney and Mitra, 1993). Another study of two year duration was conducted at Varanasi City of India with the objective to evaluate plant species responses to urban air pollution. Three tree species namely Carissa carandas, Delonix regia and Cassia fistula were studied. Reductions in plant height, basal diameter, canopy area, plant biomass, chlorophyll, ascorbic acid and nitrogen content in leaves were correlated with air pollution level at different sites. Carissa carandas was found to have more pollution tolerance level than other two species (Pandey and Agrawal, 1994).

In addition to maximizing use of low VOC emitting tree species, urban forest management strategies to help improve air quality must include followings:

- Emphasis on large and healthy trees.

- Avoid pollutant sensitive species which will, in turn, improve tree health.

- Use of more evergreen tree species for removing particulate matter.

- Plantation of trees in energy conserving locations.

- Plantation of trees to shade parked cars.

- Use of recycled or treated waste water for watering urban parks/lawns.

- Selecting species of high resistance to disease and insects as use of pesticides in high population density areas can be harmful.

- Selecting species which are drought resistant in general as trees in cities may normally face imbalances in water supply.

- For overall sustainability of urban forest, longevity of the species is also to be considered in order to avoid high removal and replacement costs for short life span species.

India and China, two Asian Giants, are among top most densely populated countries of the world. China has set an example in the field of urban forestry development, management and research during last twenty years whereas India is lagging behind in these areas (Chaudhry et al., 2011). Jim and Chen (2009) present a very vivid description of various research studies undertaken in the field of urban forestry in China, mainly on three themes: analysis of urban structure, assessment of ecosystem services emanating from them and their planning/management. The quantification and valuation of 'Air quality regulation' ecosystem service seems to have attracted maximum attention in China. Studies conducted on urban greenery of Lanzhou, Beijing and Guangzhou need special mention (Leng et al., 2004; Zhang et al., 2006; Jim and Chen, 2008). Authors 
have acknowledged few shortcomings in these studies but some rough estimates have been generated for further research and deeper understanding of urban forests in China. No research study is available in India as far as quantification of air quality improvement characteristics of urban forests in a big city was concerned. India needs to learn from China example.

\section{Conclusion}

There remains lot of scope of accumulation of scientific evidence and findings in the field of urban forestry in India. Comprehensive research database on urban forestry in the country is still lacking. To compete with other kinds of city budgets, it is essential for urban forestry to raise its public profile and publicize its multiple contributions to the public at large (Chaudhry and Tewari, 2011). Both researchers and practitioners in this field should make serious efforts to manifest the value of urban forests and to stress the mutually beneficial interactions between human society and nature (Jim and Chen 2009). Bureaucrats and political leaders from India undertake many study tours, participate in seminars, workshops, conferences in developed countries on the topics related to urban landscape, ecology and environment but seldom apply the learnt principles into practice in their own country, otherwise Indian cities would have been much cleaner and greener than at present. For betterment of India's environmentally sustainable cities, a greater awareness about the regulating, cultural and supporting ecosystem services generated by urban nature need to be fostered among political leaders, bureaucrats, civil society and general public.

\section{Conflicts of interest}

Author declare that they have no conflict of interests.

\section{References}

Akbari, H. S.; Konopacki, S. Calculating energy saving potentials of heat island reduction strategies. Energy Policy, v. 33, no. 6, p. 721756, 2005.

Anderson, L. M..; Cordell, H. K. Influence of trees on residential property values in Athens, Georgia (USA): a survey based on actual sales prices. Land Use Policy, v. 15, p. 153-164, 1988.

Attwell, K. Urban land resources and urban planning: case studies from Denmark. Landscape and Urban Planning, v. 52, no. 2/3, p. 145-163, 2000.

Chaturvedi, A.; Kamble, R.; Patil, N. G. Cityforest relationship in Nagpur: one of the greenest cities of India. Urban Forestry \& Urban Greening, v. 12, p. 79-87, 2013.

Chaudhry, P. Recreational use value of Chandigarh City's urban forestry. Current Science, v. 91, no. 11, p. 1440-1441, 2006.

Chaudhry, P.; Bagra, K.; Singh, B. Urban greenery status of some Indian cities: a short communication. International Journal of Environmental Science and Development, v. 2, no. 2, p. 1-4, 2011. Available from: $<$ http://www.ijesd.org/papers/104-D529.pdf $>$.

Accessed on: Jul. 28, 2016.

Chaudhry, P.; Sharma, M. P.; Singh, G.; Bansal, A. Valuation of urban environmental amenities in developing countries: a case study from Chandigarh, India. Global Journal of Science Frontier Research, v. 13, no. 2, p. 1-12, 2013. Available from: <https://globaljournals.org/ GJSFR_Volume13/1-Valuation-of-UrbanEnvironmental-Amenities.pdf $>$. Accessed on: Jul. 28, 2016.

Chaudhry, P.; Singh, B.; Tewari, V. P. Non market economic valuation in developing countries: role of participant observation method in CVM analysis. Journal of Forest Economics, v. 13, no. 4, p. 259-275, 2007.

Chaudhry, P.; Tewari, V. P. A comparison between TCM and CVM in assessing recreational use value of urban forestry. International Forestry Review, v. 8, no. 4, p. 439-448, 2006.

Chaudhry, P.; Tewari, V. P. Urban forestry in India: development and research scenario. Interdisciplinary Review, v. 12, no. 1, p. $98-101$, 2011. http://dx.doi.org/10.1504/IER.2011.038881

Curtis, A. J.; Helonig, D.; Baroch, C.; Daly, R.; Davis, S. Biogenic volatile organic compound emissions from nine tree species used in an urban tree planting programme. Atmospheric Environment, v. 95, p. 634-643, 2014. 
Dhadse, S.; Gajghate, D. G.; Chaudhari, P. R.; Satapathy, D. R.; Wate, S. R. Interaction of urban vegetation cover to sequester air pollution from ambient air environment. In: Moldovennu, A. M. (Ed.). Air pollution: new developments. Rijeka, Croatia: InTech, 2011.

Dwivedi, P.; Rathore, C. S.; Dubey, Y. Ecological benefits of urban forestry: the case of Kerwa Forest Area (KFA), Bhopal, India. Applied Geography, v. 29, no. 2, p. 194-200, 2009.

Gadow, K. V. Adapting silvicultural management systems to urban forests. Urban Forestry \& Urban Greening, v. 1, no. 2, p. 107-113, 2002.

Gill, S. E.; Handley, J. F.; Ennos, A. R.; Pauleit, S. Adapting cities for climate change: the role of green infrastructure, built environment. Climate Change Cities, v. 33, no. 1, p. 115134, 2007.

Govindararajulu, D. Urban green spaces planning for climate adaptation in Indian cities. Urban Climate, v. 10, no. 1, p. 35-41, 2014.

GPCB - Gujarat Pollution Control Board. 2015. Available from: <http://gpcb.gov.in>. Accessed on: Jul. 28, 2016.

Issar, T. P. Blossoms of Bangalore. Bangalore, India: Mytec Process Private Limited, 1994.

Jim, C. Y.; Chen, W. Y. Recreation amenity use and contingent valuation of urban green spaces in Guangzhou, China. Landscape and Urban Planning, v. 52, p. 117-133, 2006.

Jim, C. Y.; Chen, W. Y. Assessing the ecosystem service of air pollutant removal by urban trees in Guangzhou. Journal of Environmental Management, v. 88, p. 665676, 2008.

Jim, C. Y.; Chen, W. Y. Ecosystem services and valuation of urban forests in China. Cities, v. 26, p. 187-194, 2009.

Jo, H. K. Impacts of urban greenspace on offsetting carbon emissions for Middle Korea. Journal of Environmental Management, v. 64, p. 115-126, 2002.

Khera, N.; Mehta, V.; Sabata, B. C. Interrelationship of birds and habitat features in urban green spaces in Delhi, India. Urban Forestry \& Urban Greening, v. 8, no. 3, p. 187-196, 2009.

Kuchelmeister. G. Trees for urban millennium: urban forestry update. Unasylva, v. 51, no. 200, p. 49-55, 2000.

Kuddus, M.; Kumari, R.; Ramteke, P. W. Studies on air pollution tolerance of selected plants in Allahabad City, India. Journal of
Environmental Research and Management, v. 2, no. 3, p. 42-46, 2011.

Leindfield, M.; Steinberg, F. Green cities. Mandaluyong: Asian Development Bank, 2012.

Leng, P.; Yang, X.; Su, F.; Wu, B. Economic valuation of urban green space ecological benefits in Beijing City. Journal of Beijing Agricultural College, v. 19, no. 4, p. 25-28, 2004. (In Chinese).

Morales, D. J. The contribution of trees to residential property value. Journal of Arboriculture, v. 6, no. 11, p. 305-309, 1980.

Nagendra, H.; Gopal, D. Street trees in Bangalore: density, diversity, composition and distribution. Urban Forestry \& Urban Greening, v. 9, no. 2, p. 129-137, 2010.

Nagendra, H.; Nagendran, S.; Paul, S.; Pareeth, S. Graying, greening and Fragmentation in the rapidly expanding Indian City of Bangalore. Landscape and Urban Planning, v. 105, p. 400-406, 2012.

Nair, J. The promise of the Metropolis: Bangalore's twentieth century. New Delhi: Oxford University Press, 2005.

Nowak, D. J. Crane, D. E.; Stevens, J. Air pollution removal by urban trees and shrubs in the United States. Urban Forestry \& Urban Greening, v. 4, p. 1115-1123, 2006.

Pandey, J.; Agrawal, M. Evaluation of air pollution phytotoxicity in a seasonally dry tropical urban environment using three woody perennials. New Phytologist, v. 126, p. 53-61, 1994.

Parmar, R. N.; Singh, H. S.; Pathak, M. Assessment of status and carbon sequestration potential of green cover in the major urban development authorities of Gujarat. In: Innovative Energy Technology Systems and Environmental Concerns. A Sustainable Approach. 2015. p. 197-206.

Rai, P. K.; Panda, L. L. S. Dust capturing potential and Air Pollution Tolerance Index (APTI) of some road side tree vegetation in Aizwal, Mizoram, India: an Indo-Burma hot spot region. Air quality, Atmosphere and Health, v. 7, no. 1, p. 93-101, 2014.

Sanders, R. A. Urban vegetation impacts on the hydrology of Dayton, Ohio. Urban Ecology, v. 9, p. 361-376, 1986.

Singh, C.; Wattas, R.; Dhillon, H. S. Trees of Chandigarh. New Delhi: B. R. Publishing Corporation, 1998.

Singh, H. S. Tree density and canopy cover in the urban areas in Gujarat, India. Current Science, v. 104, no. 10, p. 1294-1299, 2013. 
Available from: <http://www.currentscience. ac.in/Volumes/104/10/1294.pdf>. Accessed on: Jul. 28, 2016.

Singh, R.; Singh, A. P.; Singh, M. P.; Kumar, A.; Varshney, C. K. Emission of isoprene from common Indian plant species and its implications for regional air quality. Environmental Monitoring Assessment, $\begin{array}{lll}\text { v. } 144, \quad \text { no. } 1, & \text { p. } 43-51, & 2008 .\end{array}$ http://dx.doi.org/10.1007/s10661-007-9940-7

Singh, V. S.; Pandey, D. N.; Chaudhry, P. Urban forests \& open green spaces: lessons for Jaipur, Rajasthan, India, an occasional paper (1/2010), RSPCB,1-23, 2010.

Taubenböck, H.; Wegmann, M.; Rooth, A.; Mehl, H.; Dech, S. Urbanisation in India: spatiotemporal analysis using remote sensing data. Computers, Environment and Urban systems, v. 33, no. 3, p. 179-188, 2009. http://dx.doi.org/10.1016/j.compenvurbsys.2008 .09.003

Tyrvainen, L. The amenity value of the urban forest: an application of the hedonic pricing method. Landscape and Urban Planning, v. 37, no. 3/4, p. 211-222, 1997.

Tyrvvainen, L. Economic valuation of urban forest benefits in Finland. Journal of Environmental Management, v. 62, no. 1, p. 75-92, 2001.

Tyrvainen, L.; Miettinen, A. Property prices and urban forest amenities. Journal of
Environmental Economics and Management, v. 39, p. 205-223, 2000.

Vailshery, L. S.; Jaganmohan, M.; Nagendra, H. Effect of street trees on microclimate and air pollution. Urban Forestry \& Urban Greening, v. 12, no. 3, p. 408-415, 2013.

Varshney, C. K.; Mitra, I. Importance of hedges in improving urban air quality. Landscape and Urban Planning, v. 25, no. 1/2, p. 85-93, 1993.

Wang, X.; Hu, Y.; Liu, X.; Gao, F.; Zhu, Q. Microclimate modification of urban grassland in Beijing. Journal of Guangxi Normal University (Natural Science Edition), v. 25, no. 3, p. 23-27, 2007. (In Chinese).

Xiao, Q.; McPherson, E. G.; Simpson, J. R.; Ustin, S. L. Rainfall interception by Sacramento's urban forest. Journal of Arboriculture, v. 24, no. 4, p. 235-244, 1998.

Xiao, Q.; McPherson, E. G. Rainfall interception by Santa Monica's Municipal Urban Forest. Urban Ecosystems, v. 6, p. 291302, 2002.

Yang, J.; Yu, Q.; Gong, P. Quantifying air pollution removal by green roofs in Chicago. Atmospheric Environment, v. 42, p. 72667273, 2008.

Zhang, W.; Zhang, F.; Yan, Z.; Zhang, Z. Initial analysis on the ecological service value of the greening land in Lanzhou City. Pratacultural Science, v. 23, no. 11, p. 98-102, 2006. (In Chinese). 